\title{
Egypt in The Age of Modern Diplomacy: Exercices of Renewable Energy
}

\author{
Togu Alexander Nadrian \\ 2015330137 \\ Mahasiswa Ilmu Hubungan Internasional, Fakultas Ilmu Sosial dan Ilmu Politik \\ Universitas Katolik Parahyangan
}

\begin{abstract}
Dalam dunia kontemporer kini, isu-isu non-tradisional menjadi suatu agenda global yang tidak kalah pentingnya untuk diselesaikan. Penggunaan power dalam era modern tidak terbatas dalam penggunaan komoditas era tradisional seperti militer. Namun komoditas baru seperti layaknya energi, lingkungan, dan agrikultur telah menjadi komoditas nasional. Diplomasi menjadi upaya yang kerap kali dilakukan suatu negara untuk mencapai kepentingan nasionalnya. Pemanfaatan komoditas baru menjadi cara yang relevan bagi negara untuk dapat mencapai kepentingannya dalam era diplomasi modern kini. Negaranegara berusaha untuk mengembangkan komoditas baru secara spesifik agar meningkatkan power sebagai kekuatan baru dalam sistem internasional. Dalam upaya mencapai kepentingan nasionalnya, Mesir telah melakukan pemberdayaan komoditas baru melalui penetapan Egypt's Vision 2030 sebagai strategi nasional. Secara garis besar, Egypt's Vision 2030 bertujuan untuk membawa Mesir kompetitif, seimbang, dan modern. Penggeseran depedensi menuju energi terbarukan menjadi cara Mesir dalam melaksanakan strategi nasionalnya. Egypt's Vision 2030 merupakan suatu langkah Mesir untuk merelevansikan negara dalam era diplomasi modern. Suatu isu yang perlu diperdebatkan melalui kemunculan langkah baru Mesir yakni peningkatan soft power Mesir untuk berdiplomasi secara regional maupun global. Maka dari itu, penulis memprakarsasi karya akademik ini dengan tuntunan pertanyaan penelitian yang berbunyi, "Mengapa usaha Pemerintah Mesir untuk beralih kepada penggunaan energi terbarukan menjadi cara baru dalam meningkatkan eksistensi Mesir dalam era diplomasi modern?”. Karya akademik ini bertujuan untuk memberikan pengetahuan hingga menciptakan suatu interpretasi yang dapat diperdebatkan mengenai upaya peningkatan dan pemberdayaan energi yang terbarukan Mesir sebagai upaya Mesir untuk meningkatkan signifikansi perannya dalam era diplomasi modern.
\end{abstract}

Keywords: Egypt's Vision 2030, modern diplomacy, middle power, soft power, renewable energy, national advantage

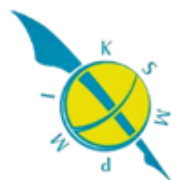




\section{Theoretical Framework: Soft Power}

Power is the ability to influence the behavior of others to get the outcomes one wants. ${ }^{1}$ Dominating actors such as empire, militant groups, and states had used traditional resources and means to achieve the outcome that they desired. Traditional resources and means such military power and intervention may enforce their progress in achieving the objectives in very short time. However, mentioned means may come with adverse feedback since it could be interpreted as coercive power. Those one-sided and traditional means are recognized as hard power. ${ }^{2}$

In the modernized world, means to achieve outcomes has been proliferated in so vary ways. For a state to achieve their goals, they shall exercise their power depending on the needs in the circumstance. Soft power comes as modern form of power. Soft power could be defined as the actor's ability to shape the preferences of others. ${ }^{3}$ Actors shall exercise their soft power to achieve their objectives within accordance of others. Soft power resources are coming from any assets that could attract others preferences.

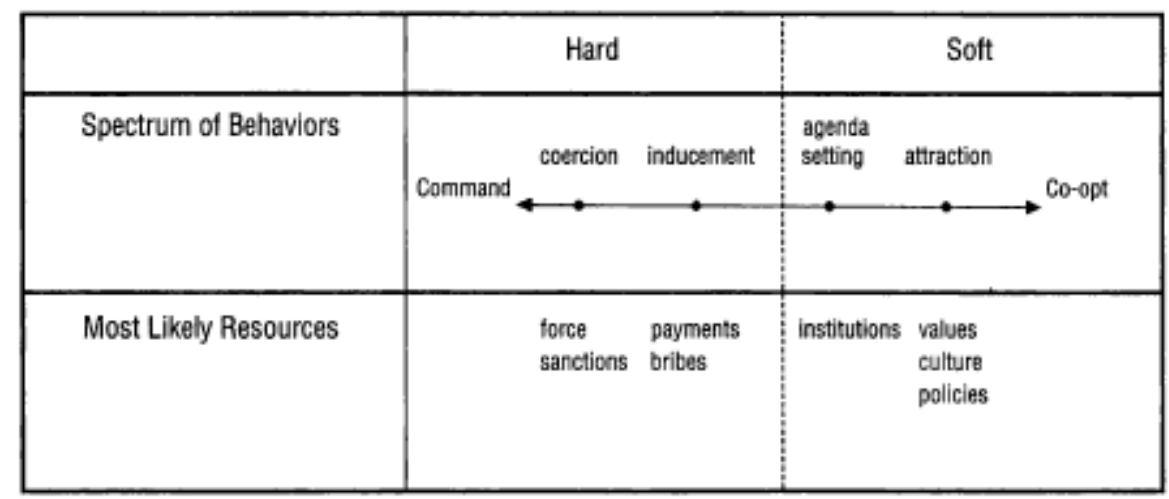

Content: Power ${ }^{4}$

${ }^{1}$ Joseph Nye, Soft Power: The Means to Success in World Politics, (New York: Public Affair $\left.{ }^{\mathrm{TM}}, 2004\right)$, p.2.

${ }^{2}$ Ibid., p.9

${ }^{3}$ Ibid., p.5

${ }^{4}$ Ibid., p.8

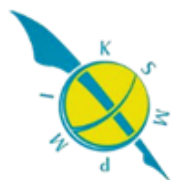


Soft power attracts other actors to cooperate. Nevertheless, soft power is not solely same as well as influence. ${ }^{5}$ Influence could be exercised through coercive action while exercising soft power does not coercively act to others. Soft power does not depend on the utilization of hard power. ${ }^{6}$

For states to exercise soft power, they shall focus on enhancing three resources within states, namely: Culture, political values, and foreign policy. ${ }^{7}$ Cultures consist of set of practical value that could shape the society. ${ }^{8}$ Cultures could be exercised through many variations such as literature, music, art, and education. The manifestation of cultures shall be accepted by society. Cultures will be easier to be accepted if it includes universal values and practice to promote values and interests that others share. ${ }^{9}$ Different cultures between states may leads to different cherished political values. Even in some cases a political values of a state may contrast with the other such as traditionalism and progressive political values. Therefore, political values may have a big role in conducting soft power. Mentioned political values will create set of foreign policy. Foreign policy is defined and created in accordance with the states security. It also shapes the exercise of soft power of state. Therefore, similarity within cultures shall play a big role in exercising soft power.

Soft power comes as attractive approach upon states. Its resources are intangible. However, it could attract and engage others. Soft power could shape others preferences by polite behavior. Soft power would be more effective to achieve states interest in nowadays era that has been more civilized.

\footnotetext{
5 Ibid., p.6

${ }^{6}$ Ibid., p. 9

${ }^{7}$ Ibid., p. 11

${ }^{8}$ Ibid.

${ }^{9}$ Ibid.
} 


\section{Energy in the Age of Modern Diplomacy}

In nowadays modernized era, the world has become so developed and invented many ideas upon things that have been existing for long time. The world has shaped into democratic world where everyone's concern shall be considered and reacted. ${ }^{10}$

Previous statement regarding modernization of the world also applied in diplomacy sector. Public had not any areas to having role in diplomacy. States within diplomacy just come up with something that become their concerned without input from the society. ${ }^{11}$ Eventually, it has been turned. Public has significant role in shaping opinion that turned into input for the states. Since public is the one that directly living within society, they shall have much more concerns regarding the society that they are living in.

The democratic world forces diplomacy to be modernized. Modern diplomacy creates platform for non-traditional issues to have prominence role in shaping the world. Non-traditional issues such as environment, trade, gender, renewable energy, etc. have been crucial as well as traditional issues to be discussed in diplomacy. ${ }^{12}$

Despite of its complexities, modern diplomacy gives states for having much option to achieving their interest. Mentioned traditional issues have given states to using domestic resources in diplomacy. Since states will exercise their domestic resources that in accordance with the non-tradition issue, states shall focus on designated resources as power to achieve their objectives in diplomacy. Even in modernized diplomacy era established new terms such as energy diplomacy, environment diplomacy, and trade diplomacy that have been shaped through the emerging of non-traditional issues. To some extent, modern diplomacy within their non-traditional issues has established new conduct of diplomacy. For an instance,

\footnotetext{
${ }^{10}$ Ronald Peter Barston, Modern Diplomacy, (New York: $4^{\text {th }}$ edition, Routledge, 2014),pg. 5

${ }^{11}$ Ibid., p.5

${ }^{12}$ Ibid.,
} 
multilateralism has not only included states, but also non-traditional actors such as business sectors, think tank, influencers for having role in multilateralism. ${ }^{13}$

Since energy is vital for economic growth, energy has become global agenda that is vital to be discussed in multilateral platform such as G20. ${ }^{14}$ How environment has become degraded forces states to shift their preference into utilization of renewable energy. States shall look for renewable energy cooperation in order to achieve their objectives. Renewable energy will create opportunity for innovation and employment that are very crucial for states secure them. Renewable energy diplomacy will be very crucial in the age of modern diplomacy. ${ }^{15}$

\section{The Beginning of Renewable Energy}

Egypt's crisis in 2011 has brought Egypt into brink age. The fall of Hosni Mobarak may be reformed political structure but also brought worst economic downfall since the great depression. ${ }^{16} 60 \%$ of foreign reserves dropped. ${ }^{17}$ The price of crude oil rose from $\$ 85.64$ in January 24, 2011 to $\$ 92.12$ in January 31, 2011. ${ }^{18}$ Egypt may be not major oil supplier in the Middle-East region, but the rises of crude oil prices may harm its cost shipment through Canal Suez. ${ }^{19}$

${ }^{13}$ Ibid., p.7

${ }^{14}$ Adnan Z. Amin, "The Age of Renewable Energy Diplomacy" International Renewable Energy Agency, November, 29, 2017 http://www.irena.org/newsroom/articles/2017/Nov/The-Age-of-Renewable-EnergyDiplomacy (accessed at May 21, 2018)

${ }^{15}$ Ibid.

16 Patrick Kingsley, "Egypt 'Suffering Worst Economic Crisis Since 1930", Guardian, May, 16, 2013 https://www.theguardian.com/world/2013/may/16/egyptworst-economic-crisis-1930s (accessed May 21, 2018)

${ }^{17}$ Ibid

${ }^{18}$ Shebonti Ray Dadwal, "The Crisis in Egypt and Its Impact on the Oil Market", Institute for Defense Studies and Analyses, May, 4, 2011 https://idsa.in/idsacomments/TheCrisisinEgyptanditsImpactontheOilMarket_srdadw al_040211 (accessed May 21, 2018)

${ }^{19}$ Ibid 
The regression of foreign reserves and oil prices harm prosperity of Egyptian. Fuel prices are sharply rose $80 \%$ from its legal rate. ${ }^{20}$ It caused another commodity to be inflated so on. Fuel prices crisis prompted food prices to be hyper inflated, thus prompted food shortage in Egypt.

\section{Energy Supply and Demand - Current Trends}

0.4

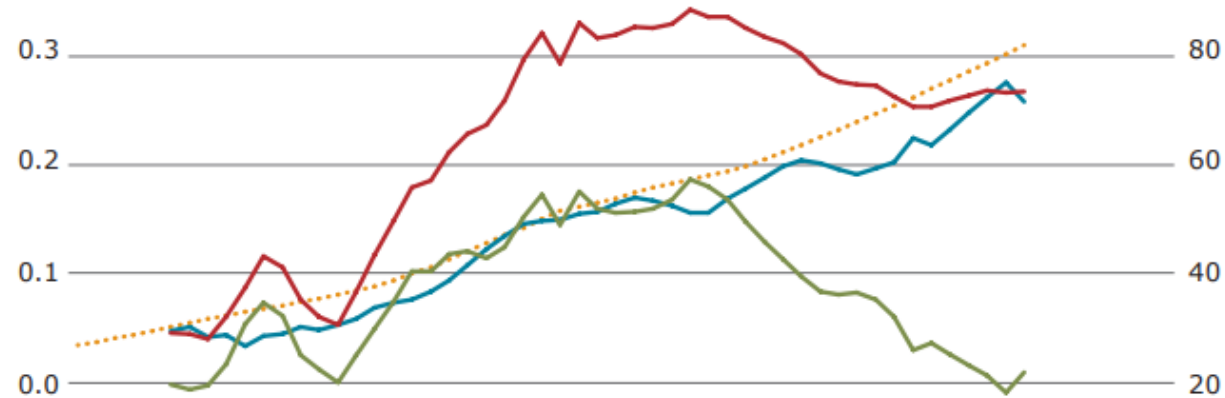

$$
\begin{aligned}
& -0.1 \\
& 1960 \\
& \text { — Production (billion barrels oil per year) } \\
& \text { — Consumption (billion barrels oil per year) } \\
& \text { — Export net (billion barrels oil per year) } \\
& \text {.... Population (millions) }
\end{aligned}
$$

Content: Oil Supply and Demand Trend in Egypt ${ }^{21}$

As the unstable of oil prices harm Egyptian prosperity, the government of Egypt looked for alternative policy to cope up the circumstances. Eventually, in February 24 2016, President Abdel Fattah El Sisi announced new Egypt's progressive sustainable development strategy mentioned as Egypt's Vision 2030. ${ }^{22}$ Egypt's

${ }^{20}$ Kingsley, loc. cit.

21 RCREEE, "Egypt: Renewable Energy Country Profile", RCREEE, 2012 http://www.rcreee.org/sites/default/files/egypt_fact_sheet_re_print.pdf (accessed in May 21, 2018)

22 "President El Sisi Unveils "Egypt Vision 2030" Sustainable Development Strategy", Embassy of Egypt in Washington D.C., 24, February, 2016 http://www.egyptembassy.net/news/news/president-el-sisi-unveils-egypt-vision2030-sustainable-development-strategy/ (accessed in 21 May, 2018)

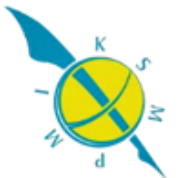


Vision 2030 aims to bring Egypt to the top 30 countries in economic and social development. ${ }^{23}$ In purpose to bring Egypt to the objectives, Egypt Vision 2030 divided into 4 respective main pillars that Egypt shall focus on, namely: Social Justice; Knowledge, innovation, and scientific research; economic development; and environment. ${ }^{24}$

All of the 4 main pillars are integrated. An improvement on a pillar will improve the others pillars. In the economic dimension, Egypt focus on several sectors included energy reform. According to the chart above, oil export quantity was declining until 2015 -but also with a little leap after 2015. Huge number of consumption of oil could harm the environment. Renewable energy will sustain the environment and provide employment. ${ }^{25}$ Therefore Egypt's Vision 2030 forces Egypt to respectively decrease the utilization of fossil fuel and enhance the capacity of renewable energy.

\section{Egypt Exercises of Renewable Energy in Modern Diplomacy Age}

Egypt has 3 main renewable energy resources, which are hydroelectricity, solar, and wind. ${ }^{26}$ Hydroelectricity has played significant role in Egypt for several years as renewable energy resources. For an instance, Egypt has issued Aswan Dam Project that produced 15,300 GWh a year. ${ }^{27}$ Geographically, Egypt has an average level of solar radiation between 2,000-3,200 KWh per-square meters a year. ${ }^{28}$ Egypt will

\footnotetext{
23 Ibid.

24 “Egypt's Vision 2030”, Sustainable Development Strategy: Egypt Vision 2030 http://sdsegypt2030.com/?lang=en (Accessed 21 May, 2018)

25 "Energy Pillar", Sustainable Development Strategy: Egypt Vision 2030, Egypt Vision 2030, http://sdsegypt2030.com/economic-dimension/energy-pillar/?lang=en (accessed May 21, 2018)

26 "Renewable Energy in Egypt: Hydro, Solar and Wind", knowledge, Norton Rose Fulbright, , last modified 2013 January http://www.nortonrosefulbright.com/knowledge/publications/74735/renewableenergy-in-egypt-hydro-solar-and-wind (accessed May 21, 2018)

27 ibid

28 ibid
} 
focus on wind to enhance the capacity of renewable energy. ${ }^{29}$ Egypt known as the best wind developed in the region. ${ }^{30}$ Zafarana district is the best wind developed area in Egypt that has created largest wind farm on shore in the world. ${ }^{31}$

Egypt has recognized as one of the significant players in developing renewable energy. By having good renewable resources as national advantage, it could increase Egypt's attractiveness in modern diplomacy. Exercising their renewable energy could create more opportunity for Egypt to seize the platform of multilateralism through soft power.

Egypt has been actively participated in multilateralism dialogue platform such as United Nations Development Programme (UNDP) and Regional Centre for Renewable Energy and Energy Efficiency (RCREEE). Once, UNDP summit was conducted in Egypt. The main idea of the summit is to ensure access to affordable, reliable, sustainable, and modern energy for all. ${ }^{32}$ This shown how the world believes that Egypt has become a prominence developer of renewable energy that feasible to conduct an UNDP meeting on renewable energy. Other than that, Egypt also recognized as the hometown of RCREEE. June 25, 2008, Cairo was assigned as host country for establishment of RCREEE through Cairo Declaration of intentions. ${ }^{33}$

Multilateralism platform shall be place for Egypt seizes the highlight to exercise Egypt's soft power. Egypt's Vision 2030 has been in accordance with inclination to exercise soft power. if we take a look on what defined as soft power resources, Egypt's Vision 2030 has fulfilled the requirement. Egypt's Vision shaped the

${ }^{29}$ ibid
30 ibid
31 ibid

32 “Goal 7: Affordable and Clean Energy",Sustainable Development Goals UNDP in Egypt, UNDP http://www.eg.undp.org/content/egypt/en/home/sdgoverview/post2015-development-agenda/goal-7.html (accessed May 21, 2008)

33 "Cairo Declaration on intentions on Establishment of Regional Centre for Renewable Energy and Energy Efficiency", RCREEE, issued on 25 June, 2008 http://www.rcreee.org/sites/default/files/legal_cairodeclaration_2008_en.pdf (accessed May 21, 2018) 
culture of Egypt to upholding clean energy. The importance of clean energy through renewable energy also has been signified by the world through Sustainable Development Program. ${ }^{34}$ This is shown that Egypt has shaped their culture in accordance with global agenda. Egypt's Vision 2030 as national agenda also shaped its foreign policy to inclination with soft power.

\section{Current Installed Capacity}

RE Targets - Year 2020
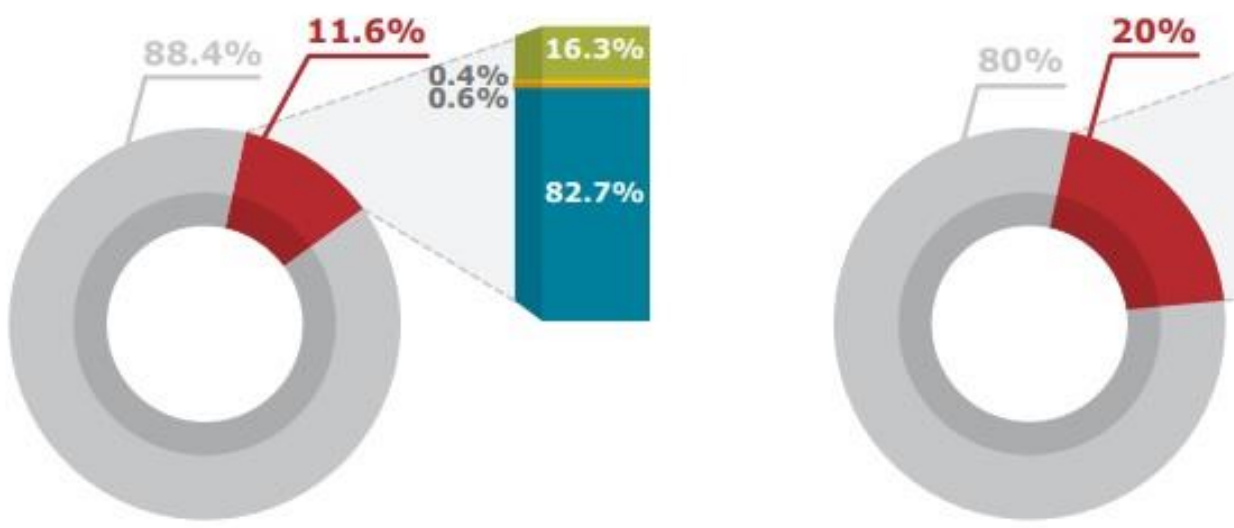

Fossil fuel RE Wind PV CSP Hydro

\begin{tabular}{|ccccccc}
\hline Wind & PV & CSP & Hydro & Total RE & $\begin{array}{c}\text { Total all Installed } \\
\text { Capacities }\end{array}$ \\
\hline MW & 550 & 15 & 20 & 2800 & 3385 & 29076 \\
\hline
\end{tabular}

\begin{tabular}{|c|c|c|c|c|}
\hline Wind & PV & CSP & Hydro & Total \\
\hline 7200 & 220 & 1100 & 2800 & 11320 \\
\hline
\end{tabular}

Content: Renewable energy capacity target ${ }^{35}$

Embracing the purpose "to possess a competitive, balanced and diversified economy, dependent on innovation and knowledge, based on justice, social integrity and participation, characterized by a balanced and diversified ecological collaboration system, investing the ingenuity of place and humans to achieve

34 "Affordable and Clean Energy", Sustainable Development Goals, UNDP http://www.undp.org/content/undp/en/home/sustainable-development-goals/goal-7affordable-and-clean-energy.html (Accessed May 21, 2018)

35 RCREEE, "Egypt: Renewable Energy Country Profile", RCREEE, 2012 http://www.rcreee.org/sites/default/files/egypt_fact_sheet_re_print.pdf (accessed in May 21, 2018)

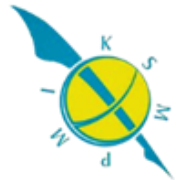


sustainable development and to improve Egyptians' life quality."36, Egypt shall not to coercively act that could harm collaboration that also harm its noble purpose. Thus, Egypt's vision 2030 has created friendly domestic circumstances for Egypt to exercise their soft power. Egypt's culture and foreign policy has been in accordance with the global agenda. This shown that Egypt is ready to be a middle power that specialized in renewable energy.

\section{Conclusion}

Egypt has great national advantages to enhance their attractiveness in modern diplomacy. Nevertheless, what become a contesting argument is does Egypt could help to stabilize the Middle-East region through their rich of renewable resources? The writer argued that Egypt could help to stabilize the Middle-East region through soft power since the Middle-East region also struggle with energy resources. Oils are depleting, renewable energy will come as alternatives. There will be need for cooperation with others to achieve creation of renewable energy. Egypt as one of the biggest resources of renewable energy, could cope up with the problem and come up with renewable energy to stabilize the region through renewable energy diplomacy in the modern diplomacy era.

36 “Egypt's Vision 2030”, Sustainable Development Strategy: Egypt Vision 2030 http://sdsegypt2030.com/?lang=en (Accessed 21 May, 2018)

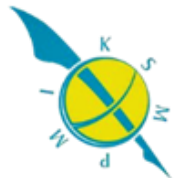




\section{References}

“Affordable and Clean Energy", Sustainable Development Goals, UNDP http://www.undp.org/content/undp/en/home/sustainable-developmentgoals/goal-7-affordable-and-clean-energy.html

Amin, Adnan Z., "The Age of Renewable Energy Diplomacy" International Renewable Energy Agency, November, 29, 2017 http://www.irena.org/newsroom/articles/2017/Nov/The-Age-of-RenewableEnergy-Diplomacy

Barston, Ronald Peter, Modern Diplomacy, (New York: $4^{\text {th }}$ edition, Routledge, 2014)

"Cairo Declaration on intentions on Establishment of Regional Centre for

Renewable Energy and Energy Efficiency”, RCREEE, issued on 25 June, 2008 http://www.rcreee.org/sites/default/files/legal_cairodeclaration_2008_en.pdf

Dadwal, Shebonti Ray, "The Crisis in Egypt and Its Impact on the Oil Market", Institute for Defense Studies and Analyses, May, 4, 2011

https://idsa.in/idsacomments/TheCrisisinEgyptanditsImpactontheOilMarket_srd adwal_040211

“Egypt's Vision 2030”, Sustainable Development Strategy: Egypt Vision 2030, http://sdsegypt2030.com/?lang=en

“Energy Pillar”, Sustainable Development Strategy: Egypt Vision 2030, Egypt

Vision 2030, http://sdsegypt2030.com/economic-dimension/energypillar/?lang=en

“Goal 7: Affordable and Clean Energy”,Sustainable Development Goals UNDP in

Egypt, UNDP

http://www.eg.undp.org/content/egypt/en/home/sdgoverview/post-2015development-agenda/goal-7.html

Kingsley, Patrick, "Egypt 'Suffering Worst Economic Crisis Since 1930”,, Guardian, May, 16, 2013

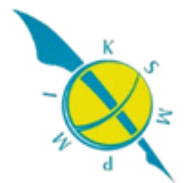


https://www.theguardian.com/world/2013/may/16/egypt-worst-economic-crisis1930s

Nye, Joseph, Soft Power: The Means to Success in World Politics, (New York: Public Affair ${ }^{\mathrm{TM}}, 2004$ )

“President El Sisi Unveils “Egypt Vision 2030” Sustainable Development Strategy", Embassy of Egypt in Washington D.C., 24, February, 2016 http://www.egyptembassy.net/news/news/president-el-sisi-unveils-egypt-vision2030-sustainable-development-strategy/

RCREEE, "Egypt: Renewable Energy Country Profile”, RCREEE, 2012 http://www.rcreee.org/sites/default/files/egypt_fact_sheet_re_print.pdf

"Renewable Energy in Egypt: Hydro, Solar and Wind", knowledge, Norton Rose Fulbright, , last modified 2013 January http://www.nortonrosefulbright.com/knowledge/publications/74735/renewableenergy-in-egypt-hydro-solar-and-wind 